\title{
The compressive strength improvement on softsoil subgrade with Quicklime stabilization, activated Gum Rosin and Iron Oxide
}

\author{
Sofwan ${ }^{1, *}$, Lawalenna Samang ${ }^{2}$, Tri Harianto ${ }^{2}$, and Achmad Bakri Muhidin ${ }^{2}$ \\ ${ }^{1}$ Hasanuddin University, Doctoral Program of Civil Engineering, Makassar, Indonesia \\ ${ }^{2}$ Hasanuddin University, Department of Civil Engineering, Makassar, Indonesia
}

\begin{abstract}
This study is intended to increase the compressive strength and durability of subgrade with lime, on high plasticity expansive soil. The composition of the stabilizing agent used; composition-1 is soil $+5 \%$ slakelime, composition- 2 is soil $+5 \%$ quicklime, and composition- 3 is soil $+5 \%$ (quicklime with rosin and iron oxide activation). The testing includes swelling test, durability test, and CBR test. That the performance of stabilization with the composition-3 was able to reduce the swelling potential on $3^{\text {th }}$ day by $93.89 \%$, decrease the volume increase potential by $93.09 \%$ and decrease the weight increase potential by $94.00 \%$ in the 3 periods of wet-dry cycle, and increase the CBR value by $758.62 \%$. That the activation of gum rosin and iron oxide on quicklime can significantly improve the performance of lime for stabilization of expansive clay as subgrade of highway.
\end{abstract}

\section{Introduction}

The pavement on the highway should be built on the subgrade with sufficient compressive strength and low shrinkage, therefore on the subgrade of expansive soil is required a stabilization.

Soil stabilization can be prepared by mechanical and chemical means. Mechanical stabilization is made by to mixing other soils gradation to improve the structure and technical properties (engineering properties). Chemical stabilization is made by adding certain chemicals to improve cohesion inter the gradation and provide resistance to water and other harmful chemicals. Lime is one of the soil stabilization material which has long been used, but the performance of lime on soft soil stabilization not provide optimal results. Previous research states that:

In the clay with lime stabilization was identified that the pure argillite underwent a slight decrease in its cohesion due to do dissolution of its clayey particles [1]. The morphological analysis suggested that's gel is formed from a result of the decomposition of the progressive clay particles in the soil reacted with the calcium ions from the lime, while $\mathrm{XRD}$ analysis provided no strong evidence in the formation of new phases [2]. Soil-lime

\footnotetext{
${ }^{*}$ Corresponding author: shofwanhd6@gmail.com
} 
mixing results in cation exchange, causing flocculation and agglomeration of soil particles, effectively increases the strength, durability and workability the soil. Such treatment also improves soil compressibility, nonetheless, but lime stabilization has a number of inherent disadvantages, such as carbonation, sulfate attack, and environment impact [3].

Expansive soil stabilized with lime and dregs ash produced maximum density at $4 \%$ lime content, unconfined strength up to ash $10 \%$, on the higher ash content the lime is not capable of binding the silicate and aluminate present in the ash. Pozzolanic reaction occurs only when there is water, and if no water then the silicate and aluminate in the ash does not mean anything so that the stabilization process is not occur [4].

Optimum lime content in the range of $5 \%$ for black cotton soil stabilization, for various lime contents and curing temperatures, it was observed that the maximum portion of strength was obtained in initial curing period of 7 days [5]. After 7 days curing period, test results show that the optimum lime content for soil stabilization is 5\% [6]. Clay is stabilized with lime and rice husk ash, the highest CBR values were achieved at $6 \%$ lime content and $4 \%$ rice husk ash content, concluded that the mixture of lime and rice husk ash is not always able to increase the value of CBR, for CBR soaked or CBR un-soaked [7].

Expansive soil, first addition with $4 \%$ of lime, second addition with $8 \%$ of bagasse ash, third addition with $4 \%$ of lime $+8 \%$ of bagasse ash. After 3 curing periods, on three types of mix its CBR value decreased, although still higher than the original soil CBR. In the second cycle, soil $+4 \%$ lime achieve the highest CBR, and decreased in the third cycle [8]. The pavement layers construction of of soil-lime was flooded every rainy season, In the fourth year, stability decreased because of puddles, decrease the carrying capacity and increase soil plasticity [9].

In the previous research which has to do with lime as a stabilize, found many weaknesses. One attempt to improve lime behavior on soft soils, is $\mathrm{CaCO}_{3}$ (Lime Stone) was made quicklime $(\mathrm{CaO})$ as a stabilizer material, gum rosin $\left(\mathrm{C}_{30} \mathrm{H}_{50} \mathrm{O}\right)$ and iron oxide $\left(\mathrm{Fe}_{2} \mathrm{O}_{3}\right)$ as activator on quicklime.

Iron oxide can affect the aggregate inter soil particles and cation exchange capacity, can indicate the condition of $\mathrm{pH}$, redox potential, moisture, and soil temperature, can react with the calcium carbonate into iron oxide-carbonate. Flocculation of the solution can be neutralized by adding an acidic substance (ion $\mathrm{H}^{+}$) [10-12]. Degree of acidity can decrease the permeability so that the soil is more stable [13].

Gum rosin is insoluble in water but can absorb water molecules, potentially as ion exchangers, and has the ability to penetrate the structure of the soil molecules that tend to be solid, has a high viscosity and good bonding properties inter particles, has high levels of carbon content [14].

\section{Methodology}

Generally, soil granules in have a high carrying capacity and excellent durability, but at a certain moisture content loses its cohesion. Therefore, the stabilization of the soil with chemicals should the imagining chemical reactions as a function of the strengthening of cohesion inter the grains in wet or dry conditions and has resistance to chemical reactions that damage. Lime stone $\left(\mathrm{CaCO}_{3}\right)$ was made quicklime $(\mathrm{CaO})$ as stabilizator, gum rosin $\left(\mathrm{C}_{30} \mathrm{H}_{50} \mathrm{O}\right)$ and iron oxide $\left(\mathrm{Fe}_{2} \mathrm{O}_{3}\right)$ as activator, researched to improve the performance of lime on expansive soft soil stabilization to subgrade of highway. 


\subsection{Testing Design}

The testing includes swelling test, durability test, and CBR test. Composition- 1 is soil + $5 \% \mathrm{CaOH}_{2}$, composition- 2 is soil $+5 \% \mathrm{CaO}$, and composition- 3 is soil $+5 \%(\mathrm{CaO}$ with $\mathrm{C}_{30} \mathrm{H}_{50} \mathrm{O}$ and $\mathrm{Fe}_{2} \mathrm{O}_{3}$ activation). For swelling test, compacted samples at the optimum moisture content, soaked in water, burdened $2,82 \mathrm{kPa}$, tested on the $3^{\text {rd }} \mathrm{day}, 5^{\text {th }}$ day, and $7^{\text {th }}$ day. For the durability test, for each soil mixture carried out wet-dry cycles 1 period, 2 period, and 3 period. 1 period is 1 time aerated for 4 days and 1 time soaked for 4 days. Swelling test and durability test do in wet-dry cycle period, CBR test do after a period of wet-dry cycles. The testing has been done in the soil mechanics laboratory of the Department of Civil Engineering Hasanuddin University Makassar. Using the testing standards ASTM D 2216-71 for the Water content test, SNI 03-1742-1989 for the Compaction test, SNI 03-1967-1990 for the Liquid limit test, SNI 03-1968-1990 for the Sieve analysis test, SNI 03-6887-2002 for the Unconfined compression test, SNI 19642008 for the Specific gravity test, SNI 1966:2008 for the Plastic limit \& Plastic Index test, and SNI 3423:2008 for the Hydrometer test.

\section{Result and Discussion}

\subsection{Soil properties}

From the atterberg limit test, the liquid limit value $(\mathrm{LL})=70.86 \%$ and plasticity index $(P I)$ $=39.46 \%$. According to Unified Soil Classification System (USCS), soil in the category of inorganic clay with high plasticity $(\mathrm{CH})$. From the sive analysis obtained the distribution of grain size of the soil, quantitatively dominated by clay fraction is $62.58 \%$, followed by silt fraction is $34.75 \%$, and sand fraction is $2.67 \%$, that this soil can be categorized as the silty clay (Bowles, 1993).

\subsection{Swelling Behaviour}

The Swelling behavior as in the Table 1 and Figure 1.

Table 1. The swelling behavior

\begin{tabular}{|l|c|c|c|c|}
\hline Sample & \% OMC & $\begin{array}{c}\text { \% Swell } \\
\text { at } 3^{\text {rd }} \text { day }\end{array}$ & $\begin{array}{c}\text { \% Swell } \\
\text { at 5 } 5^{\text {th }} \text { day }\end{array}$ & $\begin{array}{c}\text { \% Swell } \\
\text { at } 7^{\text {th }} \text { day }\end{array}$ \\
\hline Original Soil & 28.76 & 18.00 & 0.10 & 0 \\
\hline $\begin{array}{l}\text { Soil }+5 \%\left(\mathrm{CaO} \text { on } \mathrm{C}_{30} \mathrm{H}_{50} \mathrm{O} \text { and }\right. \\
\mathrm{Fe} 2 \mathrm{O} 3 \text { activation})\end{array}$ & 31.35 & 1.10 & 0 & 0 \\
\hline Soil $+5 \% \mathrm{CaO}$ & 30.02 & 3.94 & 0.45 & 0 \\
\hline Soil $+5 \% \mathrm{CaOH} 2$ & 29.27 & 5.25 & 0.82 & 0 \\
\hline
\end{tabular}




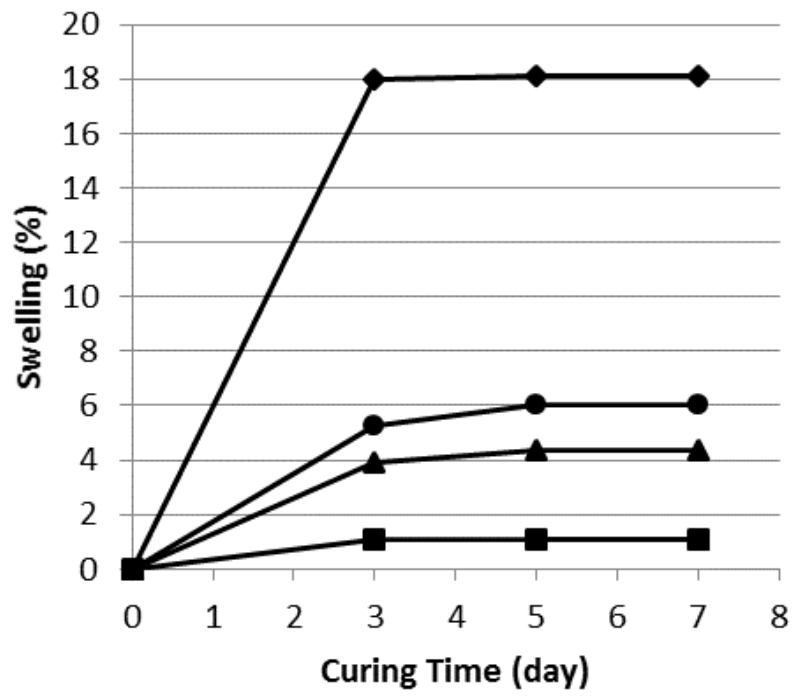

$\multimap$ Original Soil

$\rightarrow$ - Soil $+5 \%(\mathrm{CaO}$ act $\mathrm{C} 30 \mathrm{H} 50 \mathrm{O}+\mathrm{Fe} 2 \mathrm{O} 3)$

$\rightarrow$ - - Soil $+5 \% \mathrm{CaO}$

$\longrightarrow$ Soil $+5 \% \mathrm{CaOH} 2$

Figure 1. Correlation between \% swelling and curing time

In the Table 1 dan Figure 1, swelling of the original soil is $18.00 \%$. Mixed of soil + $5 \%\left(\mathrm{CaO}\right.$ on $\mathrm{C}_{30} \mathrm{H}_{50} \mathrm{O}$ and $\mathrm{Fe}_{2} \mathrm{O}_{3}$ activation) resulting in the smallest swelling rate. On the 3rd day, soil $+5 \%\left(\mathrm{CaO}\right.$ on $\mathrm{C}_{30} \mathrm{H}_{50} \mathrm{O}$ and $\mathrm{Fe}_{2} \mathrm{O}_{3}$ activation $)$ resulting in swelling rate of $1.1 \%$ or is smaller $93.89 \%$ of the original soil, while on the $5^{\text {th }}$ day and on the $7^{\text {th }}$ day there is no difference in swelling rate.

\subsection{Durabilities behavior}

The durabilities behavior as in the Table 2 and Figure 2, the Table 3 and Figure 3

Table 2. Volume change rate (\%) in the three periods of wet-dry cycles

\begin{tabular}{|l|c|c|c|c|c|c|}
\hline \multirow{2}{*}{ Sample } & \multicolumn{7}{c|}{ Volume Changes rate (\%) } \\
\cline { 2 - 7 } & Wet & Dry & Wet & Dry & Wet & Dry \\
\hline Original Soil & +20.85 & -2.85 & +1.50 & -1.40 & +1.20 & -1.20 \\
\hline $\begin{array}{l}\text { Soil }+5 \%\left(\mathrm{CaO} \text { on } \mathrm{C}_{30} \mathrm{H}_{50} \mathrm{O} \text { and } \mathrm{Fe}_{2} \mathrm{O}_{3}\right. \\
\text { activation })\end{array}$ & +1.44 & -0.34 & +0.20 & -0.20 & 0 & 0 \\
\hline Soil $+5 \% \mathrm{CaO}$ & +4.84 & -0.90 & +0.80 & -0.35 & +0.03 & 0 \\
\hline Soil $+5 \% \mathrm{CaOH}_{2}$ & +6.35 & -1.10 & +1.04 & -0.23 & 0 & 0 \\
\hline
\end{tabular}




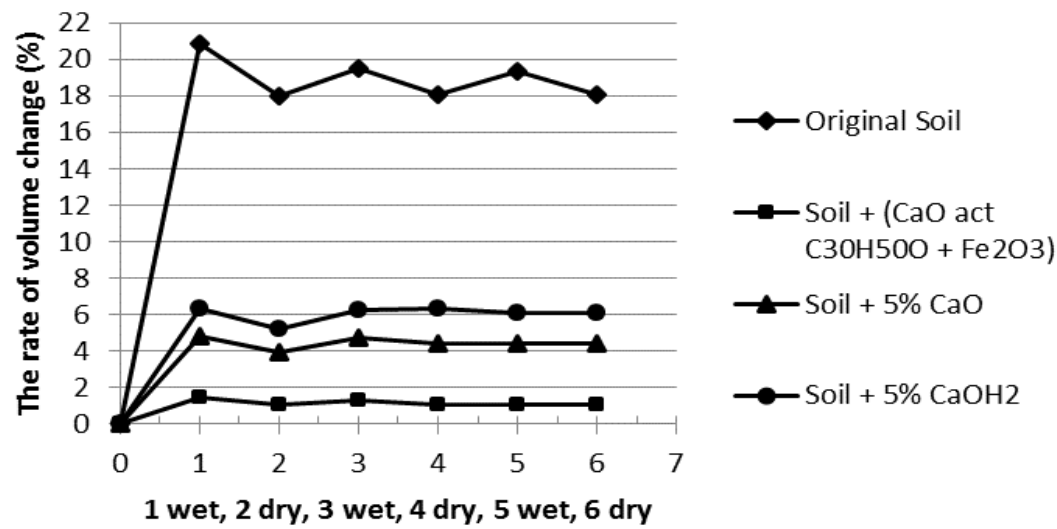

Figure 2. Correlation between $\%$ volume change rate and cycle period

Table 2 and Figure 2, after the first period of soaking the original soil increases in volume is $20.85 \%$, and after being dried by wind the volume of original soil just reduced $2.85 \%$. In the second period of soaking, increases in volume is $1.50 \%$, and after drying with the wind is reduced to $1.40 \%$. In the third period of soaking, increases in volume is $1.20 \%$, and after drying with the wind reduced to $1.20 \%$.

The composition of soil $+5 \%\left(\mathrm{CaO}\right.$ on $\mathrm{C}_{30} \mathrm{H}_{50} \mathrm{O}$ and $\mathrm{Fe}_{2} \mathrm{O}_{3}$ activation $)$ in three periods of wet-dry cycles, the increasing the volume only reached $1.44 \%$ from the volume before soaking, or smaller $93.09 \%$ of the largest volume increase on the original soil.

Table 3. Weight change rate (\%) in the three periods of wet-dry cycles

\begin{tabular}{|l|c|c|c|c|c|c|}
\hline \multirow{2}{*}{ Sample } & \multicolumn{7}{c|}{ Weight change rate (\%) } \\
\cline { 2 - 7 } & Wet & Dry & Wet & Dry & Wet & Dry \\
\hline Original Soil & +33.03 & -4.51 & +2.38 & -2.22 & +1.90 & -1.90 \\
\hline Soil $+5 \%\left(\mathrm{CaO}\right.$ on $\mathrm{C}_{30} \mathrm{H}_{50} \mathrm{O}$ and $\mathrm{Fe}_{2} \mathrm{O}_{3}$ activation $)$ & +2.28 & -0.54 & +0.32 & -0.32 & 0 & 0 \\
\hline Soil $+5 \% \mathrm{CaO}$ & +7.67 & -1.43 & +1.27 & -0.55 & +0.03 & 0 \\
\hline Soil $+5 \% \mathrm{CaOH}_{2}$ & +10.06 & -1.74 & +1.65 & -0.36 & 0 & 0 \\
\hline
\end{tabular}


Figure 3. Correlation between \% weight change rate and cycle period

Table 3 and Figure 3, in the first soaking period weight of the original soil increased by $33.03 \%$, after being dried by the wind then the weight of the original soil only decreased by $4.51 \%$. In the second period of soaking, weight of the original soil increased by $2.38 \%$, after being dried then decreased to $2.22 \%$. In the third period of soaking the weight increase by $1.90 \%$, after being dried then decreased by $1.90 \%$.

Composition of soil $+5 \%\left(\mathrm{CaO}\right.$ on $\mathrm{C}_{30} \mathrm{H}_{50} \mathrm{O}$ and $\mathrm{Fe}_{2} \mathrm{O}_{3}$ activation $)$ in the three period of wet-dry cycles experienced weight the largest gain only $2.28 \%$ of the condition before soaking, or smaller $94.00 \%$ of the largest weight gain on the original soil.

\subsection{California Bearing Ratio (CBR)}

The CBR test results are shown in the Table 4 and Figure 4.

Table 4. CBR Test Result

\begin{tabular}{|l|c|c|c|c|}
\hline \multicolumn{1}{|c|}{ Sample } & OMC (\%) & $\begin{array}{c}\text { CBR (\%) } \\
\text { First Period }\end{array}$ & $\begin{array}{c}\text { CBR (\%) } \\
\text { Second Period }\end{array}$ & $\begin{array}{c}\text { CBR (\%) } \\
\text { Third Period }\end{array}$ \\
\hline Original Soil & 28.76 & 2.32 & 1.63 & 2.09 \\
\hline $\begin{array}{l}\text { Soil }+5 \%\left(\mathrm{CaO} \text { on } \mathrm{C}_{30} \mathrm{H}_{50} \mathrm{O} \text { and } \mathrm{Fe}_{2} \mathrm{O}_{3}\right. \\
\text { activation })\end{array}$ & 31.35 & 28.34 & 34.02 & 37.62 \\
\hline Soil $+5 \% \mathrm{CaO}$ & 30.02 & 12.25 & 23.92 & 26.21 \\
\hline Soil $+5 \% \mathrm{CaOH}_{2}$ & 29.27 & 9.93 & 19.03 & 19.92 \\
\hline
\end{tabular}

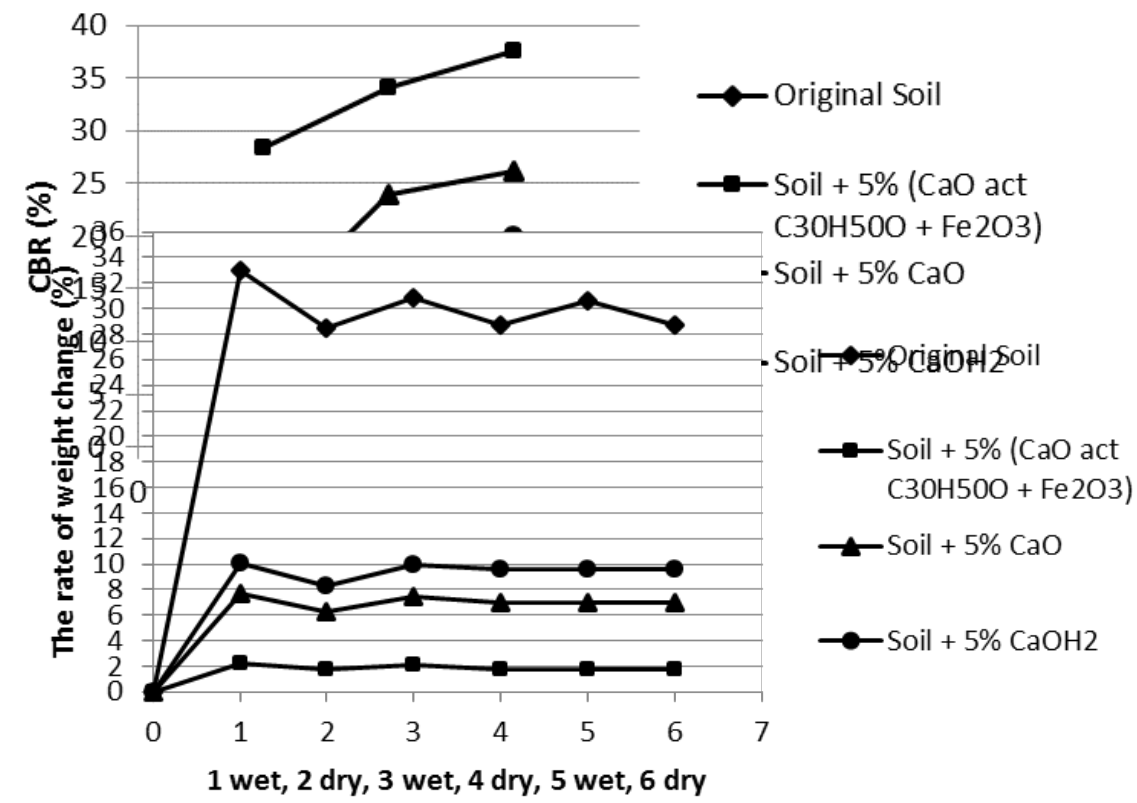

Figure 4. Correlation between CBR value (\%) and cycle period 
In the Table 4 and Figure 4, the CBR value of original soil is $2.32 \%$ and had a downward trend in the next period. To a mixture of soil $+5 \% \mathrm{CaOH}_{2}$ the $\mathrm{CBR}$ value in the first period was $9.93 \%$, greater $328.02 \%$ of the original soil CBR. In the second period the CBR value was $19,03 \%$, greater $720.26 \%$ of the original soil CBR. In the third period the CBR value was $19.92 \%$, greater $758.62 \%$ of the original soil CBR.

To a mixture of soil $+5 \% \mathrm{CaO}$ the CBR value in the first period was $12.25 \%$, greater $428.02 \%$ of the original soil CBR. In the second period the CBR value was $23.92 \%$, greater $931.03 \%$ of the original soil CBR. In the third period the CBR value was $26,21 \%$, greater $1,029.74 \%$ of the original soil CBR.

To a mixture of soil $+5 \%\left(\mathrm{CaO}\right.$ on $\mathrm{C}_{30} \mathrm{H}_{50} \mathrm{O}$ and $\mathrm{Fe}_{2} \mathrm{O}_{3}$ activation $)$ the value of CBR in the first period was $28.34 \%$, greater $1,121.55 \%$ of the original soil CBR. In the second period the CBR value was $34.02 \%$, greater $1,366.38 \%$ of the original soil CBR. In the third period the CBR value was $37.62 \%$, greater $1,521.55 \%$ of the original soil CBR.

\section{Conclusions}

That the performance of stabilization with the composition soil $+5 \%$ (quicklime with rosin and iron oxide activation) was able to reduce the swelling potential on $3^{\text {th }}$ day by 93.89\%, decrease the volume increase potential by $93.09 \%$ and decrease the weight increase potential by $94.00 \%$ in the 3 periods of wet-dry cycle, and increase the CBR value by $1,521.55 \%$. That the activation of gum rosin and iron oxide on quicklime can significantly improve the performance of lime for stabilization of expansive clay as subgrade of highway.

\section{References}

1. Cuisinier, O., Deneele, D., Masrouri, F., Shear Strength Behaviour of Compacted Clayey Soil Percolated with an Alkaline Solution. Engineering Geology 108 (2009) 177-188, journal homepage: www.elsevier.com/locate/enggeo. (2009).

2. Wild, S., Arabi, M., and Leng-Ward, G. Soil - Lime Reaction and Microstructural Development at Elevated Temperatures. Clay Minerals (1986) 21, 279-292. Received 1 July 1985; revised 3 February 1986. The Mineralogical Society. (1986).

3. Jawad, I. T., Taha, M. R., Majeed, Z. H., Khan, T. A., Soil Stabilization Using Lime: Advantages, Disadvantages and Proposing a Potential Alternative. Research Journal of Applied Sciences, Engineering and Technology 8(4): 510-520, 2014. DOI:10.19026/rjaset.8.1000. ISSN: 2040-7459; Accepted: May 10, 2014. (1914).

4. Hatmoko, J.T., dan Lulie, Y., UCS Tanah Lempung Ekspansif yang Distabilisasi dengan Abu Ampas Tebu dan Kapur. Jurnal Teknik Sipil, Volume 8 No. 1, Oktober $2007: 64$ - 77. (2007).

5. Nasrizar, A.A., Muttharam, M. Ilamparuthi, K. Role of Lime Content on Soil-Lime Reaction under Thermal Curing. Indian Geotechnical Conference - 2010, GEOtrendz. December 16-18, 2010. IGS Mumbai Chapter \& IIT Bombay. (2010).

6. Ciancio, D., Becketta, C.T.S., Carrarob, J. A. H. Optimum lime content identification for lime-stabilised rammed earth. Construction and Building Materials, 53, 59-65. DOI: 10.1016/j.conbuildmat.2013.11.077. September 12, 2013. (2013). 
7. Ariyani, N., Nugroho, A. C., Pengaruh Kapur Dan Abu Sekam Padi Pada Nilai CBR Laboratorium Tanah Tras Untuk Stabilitas Subgrade Timbunan. Majalah Ilmiah UKRIM Edisi 1/th XII/2007. (2007).

8. Sauri, S., Rachmansyah, A., Zaika, Y Pengaruh Penambahan Abu Ampas Tebu dan Kapur pada Tanah Ekspansif di Bojonegoro terhadap nilai CBR, Swelling dan Durabilitas. Jurusan Teknik Sipil Fakultas Teknik Unversitas Brawijaya, Malang 65145. . (2016).

9. Adha, I., Pengaruh Durabilitas Terhadap Daya Dukung Stabilisasi Tanah Menggunakan Lempung Plastisitas Rendah Dengan Kapur. Jurnal Rekayasa Vol. 13 No. 3, Desember 2009. (2009).

10. Cornell, R.M., Schertmann, U., (1996). The Iron Oxides: Structure, Properties, Reactions, Occurrence and Uses. VCH Publishers: Weinheim, Germany.

11. Rossel, R.V., Cattle, S., Ortega, A., Fouad, Y., In Situ Measurements of Soil Colour, Mineral Composition and Clay Content by Vis-NIR Spectroscopy. Geoderma 150, 253266. (2009).

12. Mitchel, J.K., Fundamental of Soil Behaviour. John Wiley and Sons, lnc., New York. (1976).

13. Nordstrom, D. K., Negative $p H$ and Extremely Acidic Mine Waters from Iron Mountain, California. Environmental Science \& Technology 34 (2), 254-258. (2000).

14. Doelen, V.D., Berg, V.D., Boon, J.J., a. Comparative Chromatographic and Mass Spectrometric Studies of Triterpenoid Varnishes Fresh Material and Aged Samples from Paintings. Studies in Conservation. 43(4). 249-264. (1998).

15. ASTM D 2216-71. Standard Test Methods for Laboratory Determination of Water (Moisture) Content of Soil and Rock. by Mass ${ }^{1}$

16. SNI 03-1742-1989. Panduan pengujian kepadatan ringan untuk tanah Standar Nasional Indonesia. Bahan Konstruksi Bangunan Dan Rekayasa Sipil.

17. SNI 03-1967-1990. Metode pengujian batas cair tanah dengan alat Cassagrande.

18. SNI 03-1968-1990. Agregat halus dan kasar, Metode pengujian analisis saringan.

19. SNI 03-6887-2002. Metode pengujian kuat tekan bebas campuran tanah-semen.

20. SNI 1964:2008. Cara uji berat jenis tanah tanah. Revisi dari SNI 03-1964-1990.

21. SNI 1966:2008. Cara uji penentuan batas plastis dan indeks plastisitas tanah. Revisi dari SNI 03-1966-1990

22. SNI 3423:2008. Cara uji analisis ukuran butir tanah. Revisi dari SNI 03-3423-1994. 